(C) 2018. This manuscript version is made available under the CC-BY-NC-ND 4.0 license http://creativecommons.org/licenses/by-nc-nd/4.0/

\title{
Iron-loaded Sphagnum moss extract residue for phosphate removal
}

Ruichi Zhanga ${ }^{\mathrm{a}}$, Tiina Leiviskäa ${ }^{*}$, Sanna Taskila $^{\mathrm{a}}$, Juha Tanskanen ${ }^{\mathrm{a}}$

${ }^{a}$ University of Oulu, Chemical Process Engineering, P.O. Box 4300, FIN-90014 University of Oulu, Oulu, Finland.

E-mail: ruichi.zhang@oulu.fi (R. Zhang), sanna.taskila@oulu.fi (S. Taskila), juha.tanskanen@oulu.fi (J. Tanskanen).

* Corresponding author. E-mail: tiina.leiviska@oulu.fi (T. Leiviskä), Tel +358-294482386.

\section{Abstract}

Sphagnum moss extract residue (SMER), obtained after pressurized hot water extraction, was modified with Fe(III) and investigated for phosphate sorption. Although moss extract contains value-added compounds, SMER is considered to be waste until suitable uses can be developed. The effect of modification conditions were investigated, i.e. different initial $\mathrm{Fe}(\mathrm{III})$ concentrations $\left(0.024,0.048\right.$ and $\left.0.072 \mathrm{~mol} / \mathrm{L} \mathrm{Fe}^{3+}\right)$ and modification $\mathrm{pH}$ values (5, 7 and 9). A modification $\mathrm{pH}$ of 5 and the highest initial $\mathrm{Fe}(\mathrm{III})$ concentration $(0.072$ $\mathrm{mol} / \mathrm{L} \mathrm{Fe}^{3+}$ ) resulted in the highest phosphate removal efficiency, and thus was selected for further study. The removal efficiency was found to decreased with increasing $\mathrm{pH}$ in the range of 3-9. Maximum removal efficiency (82\%) for phosphate sorption was observed at pH 3 after 24 h contact time (dosage $2 \mathrm{~g} / \mathrm{L}$, initial concentration $15 \mathrm{mg}$ P/L). With increased contact time, the phosphate removal efficiency improved and reached equilibrium within $48 \mathrm{~h}$. The Elovich model was found to provide the best fit to the kinetic data. A capacity of $9-13 \mathrm{mg} \mathrm{P} / \mathrm{g}$ was obtained with a 24 -hour contact time at $\mathrm{pH} 4$. A 
good fit was achieved with the Redlich-Peterson equation. FTIR analysis confirmed that carboxylic acid groups were involved in the modification process. X-ray diffraction analyses showed that amorphous two-line ferrihydrite was precipitated onto SMER, which was supported by X-ray photoelectron spectroscopy analyses.

Keywords: Hot water extraction, Iron(III) modification, Surface composition, Sorption, Ferrihydrite

\section{Introduction}

Phosphorus is a very important nutrient for living creatures. Generally, the content of phosphorus in natural water bodies is assumed to be extremely low. However, over the past decade, the discharge of phosphorus has increased significantly through agricultural wastes, municipal wastewater, expansion of fossil fuel combustion and the use of fertilisers. Phosphate in wastewaters has drawn a lot of attention in recent years. Various conventional technologies are available for phosphate removal such as membrane filtration, coagulation and flocculation, and biological assimilation. Nevertheless, problems of high cost, sludge and waste disposal, and operation difficulties have always posed a major challenge for these conventional methods (Gupta and Ali, 2012; Xu et al., 2016).

As one of the wastewater treatment technologies with the most potential, sorption has received a lot of attention due to its low cost and ease of operation (Ali et al., 2012; Adegoke et al., 2013; Ali et al., 2016a; Ali et al., 2016b; Dehghani et al., 2016; Xu et al., 2016). Numerous virgin or activated low-cost sorbents such as agricultural products (wheat straw, rice husk, cotton seed hulls and sugar beet pulp), natural residues (sawdust, 
bark, peat and peat moss), industrial wastes (fly ash, red mud, petroleum wastes, scrap tyres and blast furnace slag), marine biomasses (sea weed and algae) and some other biological materials (fungi, yeast, chitosan and bacterial biomass) have been investigated (Ali et al., 2012; Ali et al., 2014; Bhatnagar and Minocha, 2006; Crini, 2006; Khan et al., 2011).

Sphagnum moss is a plant that grows in moist and wet areas, whereas peat moss is partially decomposed plant material (e.g. from Sphagnum moss). These materials are complex biomaterials comprising lignin-like substances and cellulose as the major components, as well as humic substances. Sphagnum moss is widely available due to its abundance; according to Charman (2002), globally peatlands cover an area of some four million square metres, with a renewing rate of 50,000 ha/a. The high content of oxygencontaining functional groups, large specific surface area and high porosity enable Sphagnum moss and peat moss to uptake various pollutants (mainly metal cations) through ion exchange, complexation and other reactions (Babel and Kurniawan, 2003; Gardea-Torresdey et al., 1996).

As Sphagnum moss contains various high-value bioactive constituents with antioxidative (Tarnawski et al., 2006), antimicrobial (Baas et al., 2000) or otherwise medically interesting properties (Gamenara et al., 2001; Yamada et al., 2007), it is feasible to employ a cascade approach starting with extraction, after which the biomass residue remains useful for the production of biosorbent for wastewater treatment. This study focuses on the utilization of Sphagnum moss extract residue (SMER) as a novel support material, onto which iron compounds would be introduced to improve the phosphate 
sorption capacity. A further benefit of using the residue in water treatment is its low leaching characteristics (e.g. low humic content).

In general, the sorption ability of biomaterials as such is inadequate for anionic pollutants (Ali et al., 2015; Xu et al., 2016). Therefore, a variety of modification methods have been developed, among which metal-impregnated biomass has attracted a great deal of interest. Commonly used metal ions include $\mathrm{Zr}(\mathrm{IV}), \mathrm{Al}(\mathrm{III})$ and $\mathrm{Fe}(\mathrm{III})$. Iron-modified biosorbents have been used to remove various anionic species such as As(III) and As(V) (Aryal et al., 2010), Cr(VI) (Li et al., 2004) and phosphate. Some studies on Fe(III)-loaded materials for phosphate removal are listed in Table 1. As can be seen from the table, good sorption capacities were obtained. However, very little is known about the optimal iron modifications for biosorbents and only few articles have studied the type of iron compounds loaded on the biosorbents. Modification $\mathrm{pH}$, for example, has a significant effect on the composition and structure of iron oxide (Adegoke et al., 2013). Further research on iron modification is thus of great importance.

Table 1. Phosphate sorption capacities of some iron-loaded materials

\begin{tabular}{lll}
\hline Biomaterial & $\begin{array}{l}\text { Sorption } \\
\text { Capacity } \\
(\mathrm{mg} \mathrm{P} / \mathrm{g})\end{array}$ & \\
& 13.9 & References \\
\hline Fe(III)-loaded orange waste & 34.1 & Liao et al. (2006) \\
Fe(III)-loaded collagen fibre & 46.6 & Cui et al. (2016) \\
Fe(III)-loaded cellulose nanofibres & 4.8 & Nguyen et al. (2013) \\
Fe(III)-loaded okara & 23.1 & Krishnan \& Haridas (2008) \\
Fe(III)-loaded coir pith & 2.8 & Eberhardt and Min (2008) \\
Fe(III)-loaded wood particles & 4.1 & Eberhardt and Min (2008) \\
Anionic polymer and Fe(III)-loaded wood & & \\
particles & & \\
\hline
\end{tabular}


In view of the above, the present work investigated the optimum modification process for iron-modified SMER. The modification $\mathrm{pH}$ and initial concentration of the $\mathrm{Fe}$ (III) solution were studied. Subsequently, phosphate sorption tests were conducted to determine the capacity of the product, the effect of contact time and the optimal $\mathrm{pH} . \mathrm{X}$ ray diffraction (XRD), Fourier transform infrared spectroscopy (FTIR) and X-ray photoelectron spectroscopy (XPS) were used to study the characteristics of Fe(III)-loaded SMER, providing new knowledge about both the iron-binding and the phosphate-binding mechanisms.

\section{Materials and methods}

\subsection{Raw materials and chemicals}

SMER was provided by the Natural Resources Institute of Finland. Sphagnum magellanicum moss was collected from Pehkeensuo (a small sedge bog) in Utajärvi, Finland. Sphagnum moss was treated by pressurized hot water extraction (15 bar) using a 300-litre extraction unit (Kilpeläinen et al., 2014). Sphagnum moss (18 kg, 7.8\% dry matter content) was loaded into the extraction chamber. Preheated water $\left(180^{\circ} \mathrm{C}\right)$ was pumped through the extraction chamber at a flow rate of $20 \mathrm{~kg} / \mathrm{min}$ for one hour. Then the extract and residue (SMER) were cooled down and the SMER was frozen and stored. The extract was used for other purposes. In the modification experiment, melted SMER was dried at $80^{\circ} \mathrm{C}$ for $24 \mathrm{~h}$, then ground and sieved to retain the $250-500 \mu \mathrm{m}$ fraction.

$\mathrm{Na}_{3} \mathrm{PO}_{4}$ (Sigma-Aldrich) was used to prepare different concentrations of phosphate solution. Diverse iron concentration solutions were prepared by dissolving $\mathrm{FeCl}_{3} \cdot 6 \mathrm{H}_{2} \mathrm{O}$ (Merck) in pure Milli-Q water (Merck Millipore). $\mathrm{HCl}$ (Merck) and $\mathrm{NaOH}$ (SigmaAldrich) were used for $\mathrm{pH}$ adjustment. LCK-350 phosphate cuvettes (Hach-Lange, 
Germany) were used for the analysis of phosphate after the sorption test. All the chemicals used were of analytical quality.

\subsection{Biosorbent characterization}

Five samples were prepared for characterization: virgin SMER, iron-modified SMER at different modification $\mathrm{pH}$ values $(5,7$ and 9$)$ with the highest iron concentration $(0.072$ $\mathrm{mol} / \mathrm{L} \mathrm{Fe}^{3+}$ ), and phosphate-treated iron-modified SMER (modification $\mathrm{pH} 5$ with the highest iron concentration). Samples were characterized using XRD, FTIR and XPS. One gram of each sample was ground to fine powder with a hand mortar and then collected for XRD and FTIR analyses. A small fraction of the samples (as such, without grinding) were used for XPS.

XRD analyses were conducted using a Rigaku Smartlab diffractometer and a Co lamp $(40 \mathrm{kV}, 135 \mathrm{~mA})$. The samples were measured at room temperature using Bragg-Brentano para-focusing geometry (300 $\mathrm{mm}$ goniometer). The speed of acquisition was $3 \mathrm{deg} / \mathrm{min}$ at $0.02 \mathrm{deg} / \mathrm{step}$. FTIR spectra were measured using a Bruker Vertex V80 vacuum FTIR spectrometer, which was connected to a computer containing the OPUS program to display the recorded spectra. The FTIR spectra were recorded in the $400-4000 \mathrm{~cm}^{-1}$ wave number region. XPS was carried out with a Thermo Fisher Scientific ESCALAB 250Xi and using a monochromatic Al Ka source (1486.6 eV). Wide-scan spectra were recorded in steps of $1 \mathrm{eV}$ and a pass energy of $150 \mathrm{eV}$, and high-resolution spectra with steps of $0.1 \mathrm{eV}$ and a pass energy of $20 \mathrm{eV}$. The charge correction was performed by setting the binding energy of adventitious carbon to $284.8 \mathrm{eV}$.

2.3 Biomass modification and batch sorption test 
A full factorial design was chosen to investigate the biomass modification. The two factors investigated were initial iron concentration $\left(0.024,0.048\right.$ and $\left.0.072 \mathrm{~mol} / \mathrm{L} \mathrm{Fe}^{3+}\right)$ and modification $\mathrm{pH}(5,7$ and 9). Phosphate removal efficiency was selected as the response. The results were evaluated by computing the coefficients using multiple linear regression (Modde 12.0 software, Umetrics $A B$ ). The coefficient was considered significant if the $\mathrm{p}$ value was below 0.05 .

The experiment was conducted at room temperature. Two repeats were conducted for each iron concentration under the same modification $\mathrm{pH}$. The modification process was conducted as follows: $1 \mathrm{~g}$ SMER was treated with $50 \mathrm{~mL} \mathrm{Fe}(\mathrm{III})$ solution. The modification $\mathrm{pH}$ was adjusted to the desired value $(5,7$ or 9$)$. Next, the mixture was agitated by magnetic stirring at room temperature $\left(20 \pm 3{ }^{\circ} \mathrm{C}\right)$ for $6 \mathrm{~h}$. After that, the modified SMER was separated from the solution by centrifugation (Jouan C4.12, 10 minutes, $2500 \mathrm{rpm})$. The sample was washed several times with water until the $\mathrm{pH}$ reached neutral and the solution became clear and colourless. Then the final product was dried at $80^{\circ} \mathrm{C}$ for $26 \mathrm{~h}$.

Fe(III)-treated and virgin SMER were then used for the removal of phosphate from aqueous solutions. Samples were weighed $(0.1 \mathrm{~g})$ and transferred into polypropylene bottles, followed by the addition of $50 \mathrm{~mL}$ of phosphate solution with a concentration of $15 \mathrm{mg} \mathrm{P} / \mathrm{L}$. The $\mathrm{pH}$ of the phosphate solution was pre-adjusted to 5.4-5.6. The batch experiment for each product was done in duplicate. The bottles were then shaken for 24 $\mathrm{h}$ at room temperature at a speed of $20 \mathrm{rpm} / \mathrm{min}$. After two hours, $\mathrm{pH}$ readjustment was performed for each sample by adding $\mathrm{HCl}$ or $\mathrm{NaOH}$ to prevent $\mathrm{pH}$ change, thus ensuring the accuracy of the experiments. After the sorption test, the sample was centrifuged (10 
min, $2500 \mathrm{rpm}$ ) and filtered with a $0.45 \mu \mathrm{m}$ membrane, then analysed for residual phosphate content. On the basis of the results, the SMER modified at pH 5 and with the highest Fe concentration was selected for further study (capacity, contact time and $\mathrm{pH}$ ).

\subsection{Phosphate removal capacity}

The phosphate sorption capacity was determined for two batches (batches 1 and 2) of modified SMER (pH 5, Fe $0.072 \mathrm{~mol} / \mathrm{L}$ ). Sorption tests were performed with a similar procedure as that mentioned in section 2.3. Different initial concentrations of phosphate solution (10-175 mg P/L) were prepared and the $\mathrm{pH}$ of the solution was pre-adjusted to 4. Other parameters, i.e. the contact time $(24 \mathrm{~h})$ and biosorbent dosage $(2 \mathrm{~g} / \mathrm{L})$, were kept constant. All the experiments were done in triplicate. Sorption capacity was calculated using the following equation (1):

$\mathrm{q}_{\mathrm{e}}=\frac{\left(\mathrm{C}_{0}-\mathrm{C}_{\mathrm{e}}\right) \mathrm{V}}{\mathrm{m}}$

where $\mathrm{q}_{\mathrm{e}}$ is the phosphate sorption capacity $(\mathrm{mg} / \mathrm{g}) ; \mathrm{C}_{0}$ is the concentration of phosphate ions in the initial solution $(\mathrm{mg} / \mathrm{L}) ; \mathrm{C}_{\mathrm{e}}$ is the residual phosphate concentration in solution after the sorption test $(\mathrm{mg} / \mathrm{L}) ; \mathrm{V}$ is the volume of the solution $(\mathrm{L})$; and $\mathrm{m}$ is the weight of the biosorbent (g). The non-linear Langmuir, Freundlich and Redlich-Peterson isotherms were used to evaluate the experimental adsorption data (supplementary material).

2.5 Effect of $\mathrm{pH}$ of aqueous media

Batch experiments to test the effect of $\mathrm{pH}$ were conducted at seven different $\mathrm{pH}$ levels: 3 , $4,5,6,7,8$ and 9. Other parameters, i.e. the initial concentration of the phosphate solution (15 mg P/L), contact time (24 h) and biosorbent dosage (2 g/L), were kept constant. All 
the tests were performed in duplicate, following a similar batch procedure as that described in section 2.3.

\subsection{Effect of contact time}

The effect of different contact times (10 mins, 30 mins, 1 h, 6 h, 24 h, $48 \mathrm{~h}$ and $72 \mathrm{~h}$ ) was investigated by using $15 \mathrm{mg} \mathrm{P} / \mathrm{L}$ phosphate solution as the initial phosphate concentration with a $\mathrm{pH}$ value of 4 at room temperature. The biosorbent dosage was $2 \mathrm{~g} / \mathrm{L}$. $\mathrm{pH}$ readjustment was performed after two hours of shaking for the samples with contact times of $6,24,48$ and $72 \mathrm{~h}$. All the experiments were done in duplicate, following a similar batch procedure as that described in section 2.3. Three kinetic models (pseudo-first-order, pseudo-second-order and Elovich) were used to analyse the kinetic data (in the supplementary material). The non-linear method was applied to determine the parameters of the kinetic models.

\section{Results and discussion}

\subsection{Biosorbent characterization}

\subsubsection{XRD analysis}

The XRD profiles of virgin SMER, iron-modified SMER $\left(0.072 \mathrm{~mol} / \mathrm{L} \mathrm{Fe} \mathrm{Fe}^{3+}\right.$ concentration) at three different modification $\mathrm{pH}$ values $(5,7$ and 9), and phosphatetreated modified SMER (modification $\mathrm{pH}$ 5) are shown in Fig. 1. Small peaks were observed in the $2 \theta$ range of $30-40^{\circ}$ in the XRD pattern of virgin SMER, which disappeared after iron modification. In addition, the loaded iron was in the amorphous phase as indicated by the XRD pattern, hence amorphous iron oxyhydroxide existed in the modified SMER. Two broad peaks with a d-value of $0.26 \mathrm{~nm}\left(2 \theta \approx 40^{\circ}\right)$ and $0.15 \mathrm{~nm}$ 
$\left(2 \theta \approx 75^{\circ}\right)$ are characteristic of two-line ferrihydrite (Cornell and Schwertmann, 2003; Mathew et al., 2011). XRD analysis thus indicated that two-line ferrihydrite was loaded on the SMER and the iron was in trivalent state. Several formulae of ferrihydrite have been proposed in the past, but $5 \mathrm{Fe}_{2} \mathrm{O}_{3} \cdot 9 \mathrm{H}_{2} \mathrm{O}$ is the most commonly used formula in the literature (Mallet et al., 2013).

Fig. 1 a single-column fitting image

Two-line ferrihydrite and six-line ferrihydrite are two commonly distinguished types of ferrihydrite. Lewis and Cardile (1989) demonstrated that acid hydrolysis of dilute $\mathrm{Fe}\left(\mathrm{NO}_{3}\right)_{3}$ solutions at room temperature resulted in six-line ferrihydrite, whereas two-line ferrihydrite was produced by quick basic hydrolysis. The modification conditions used in this study thus favour the formation of two-line ferrihydrite. The strong adsorptive capacity and large surface area of two-line ferrihydrite enable it to take up various water

pollutants (Das et al., 2010). Ferrihydrite is the unstable phase of iron oxyhydroxide. Under certain conditions, it will transform slowly over time into more stable and more crystalline phases, i.e. hematite and goethite (Schwertmann et al., 1999). Hematite formation is enhanced close to the point of zero charge ( $\mathrm{pH}_{\mathrm{PZC}}$ ) of two-line ferrihydrite or at higher temperature, whereas goethite is formed at $\mathrm{pH}$ values well above or below the $\mathrm{pH}$ PZC.

\subsubsection{FTIR}

Fig. 2 shows the FTIR spectra of virgin and iron-modified SMER (pH 5 with $0.072 \mathrm{~mol} / \mathrm{L}$ $\mathrm{Fe}^{3+}$ concentration). Bands at 1730 and $1610 \mathrm{~cm}^{-1}$ may be associated with $\mathrm{C}=\mathrm{O}$ stretching vibrations. The band from 1650 to $1600 \mathrm{~cm}^{-1}$ was attributed to the carbonyl bond from carboxylic groups $\left(\mathrm{COO}^{-}\right)$, while the band at $1730 \mathrm{~cm}^{-1}$ refer to the carbonyl bond from 
carboxylic acid compounds $(-\mathrm{COOH})$ and esters (Bulgariu et al., 2011). After iron modification, a significant change was observed. The band from $1730 \mathrm{~cm}^{-1}$ became very weak and shifted to a lower wave number $\left(1722 \mathrm{~cm}^{-1}\right)$. Conversely, the band at $1610 \mathrm{~cm}^{-}$

${ }^{1}$ was enhanced, which indicated that carboxylic acid groups had reacted with the iron compounds. This supports previous findings that carboxylic acid groups are responsible for the binding of iron on biomass (Aryal et al., 2010). The binding of Fe(III) ions to carboxylic acid groups is based on the ion exchange mechanism. Gardea-Torresdey et al. (1996) demonstrated that other functional groups such as phenol also bound $\mathrm{Cu}$ (II) to Sphagnum peat moss. After treating with phosphate, no obvious changes were observed in the intensities of carboxylic acid groups.

Fig. 2. a single-column fitting image

\subsubsection{XPS analysis}

The elemental compositions of virgin SMER, iron-modified SMER $\left(0.072 \mathrm{~mol} / \mathrm{L} \mathrm{Fe}^{3+}\right)$ at three different modification $\mathrm{pH}$ values (5, 7 and 9), and phosphate-treated modified SMER (modification $\mathrm{pH}$ 5) are listed in Table 2. The corresponding Fe:O and O:C ratios were also calculated and included. Iron was successfully impregnated on SMER during the modification process (Table 2). The Fe:O ratio was 1:2.6 and 1:2.5 for modification $\mathrm{pH}$ values of 5 and 7, respectively. However, the ratio changed to 1:3.3 when the highest modification $\mathrm{pH}$ of 9 was used. The atomic percentage of iron on the surface of ironmodified SMER was $17.6 \%$ for $\mathrm{pH} 5$ and $18.5 \%$ for $\mathrm{pH}$ 7, which were higher values than for iron-modified SMER in alkaline conditions (11.7\%). This indicated that more iron could be loaded on SMER under lower $\mathrm{pH}$ conditions. As the modification process dramatically changed the chemical composition of the SMER surface, the ratio of O:C 
also increased. The carbon content decreased while the oxygen content increased, but the changes were not so significant when alkaline modification $(\mathrm{pH} 9)$ was applied in comparison with modification $\mathrm{pH}$ values of 5 or 7.

Table 2. Surface composition (at.\%) of virgin, iron-modified $\left(0.072 \mathrm{~mol} / \mathrm{L} \mathrm{Fe} \mathrm{Fe}^{3+}\right.$ concentration) and phosphate-treated iron-modified SMER (initial concentration of phosphate $=15 \mathrm{mg}$ P/L)

\begin{tabular}{llllllllll}
\hline Biosorbent type & $\mathrm{pH}$ & \multicolumn{7}{c}{ Atomic percentage of the elements (\%) } \\
& & $\mathrm{C}$ & $\mathrm{Fe}$ & $\mathrm{O}$ & $\mathrm{N}$ & $\mathrm{P}$ & $\mathrm{Fe}: \mathrm{O}$ & $\mathrm{O}: \mathrm{C}$ \\
\hline Virgin SMER & - & 74.0 & - & 25.0 & 1.1 & - & - & $1: 3.0$ \\
Modified SMER & 5 & 36.8 & 17.6 & 44.9 & 0.7 & - & $1: 2.6$ & $1: 1.3$ \\
Modified SMER & 7 & 34.2 & 18.5 & 46.4 & 0.9 & - & $1: 2.5$ & $1: 1.4$ \\
Modified SMER & 9 & 48.9 & 11.7 & 38.5 & 1.0 & - & $1: 3.3$ & $1: 0.8$ \\
P-treated modified SMER & 5 & 35.9 & 15.0 & 46.3 & 0.9 & 2.0 & $1: 3.1$ & $1: 1.3$ \\
\hline
\end{tabular}

The O 1s spectra of virgin SMER, iron-modified SMER at three different modification $\mathrm{pH}$ values (5, 7 and 9), and phosphate-treated iron-modified SMER (modification $\mathrm{pH}$ 5) are shown in Fig. 3. The virgin SMER sample displayed a peak centred at $532.8 \mathrm{eV}$, which was assumed to be mainly the organic $\mathrm{C}-\mathrm{O}$ in the SMER but there should also be $\mathrm{C}=\mathrm{O}$ bonding on the lower BE side of that peak (Nguila Inari et al., 2006; Pereira et al., 2014). The O 1s spectra of iron-loaded SMER were fitted with three peaks: organic C-O bonding $(532.9 \mathrm{eV} \pm 0.1 \mathrm{eV}), \mathrm{Fe}-\mathrm{OH}$ bonding and $\mathrm{C}=\mathrm{O}$ bonding $(531.5 \pm 0.2 \mathrm{eV})$, and Fe-O bonding (530.1 $\pm 0.2 \mathrm{eV}$ ) (Cui et al., 2016; Nguila Inari et al., 2006; Mallet et al., 2013; Popescu et al., 2009). After phosphate treatment, the $\mathrm{O}-\mathrm{P}$ bonding obtained is assumed to be included in the middle peak along with $\mathrm{Fe}-\mathrm{OH}$ and $\mathrm{C}=\mathrm{O}$ bonding $(531.5$ eV, Fig. 3e) (Mallet et al., 2013).

Fig. 3. a 2-column fitting image 
The shape of the Fe $2 \mathrm{p}$ spectra under different modification $\mathrm{pH}$ values was almost the same (Fig. S1), which supported the XRD data that the same iron compound, i.e. two-line ferrihydrite, was loaded on the SMER. The Fe 2 $\mathrm{p}_{3 / 2}$ and Fe $2 \mathrm{p}_{1 / 2}$ peaks of the iron-loaded SMER samples had binding energies at $711.1 \pm 0.2 \mathrm{eV}$ and $724.3 \pm 0.3 \mathrm{eV}$, which correspond to the binding energy of ferrihydrite (Frau et al., 2010; Mallet et al., 2013). However, it should be noted that some other iron compounds such as akaganéite ( $\beta$ FeOOH) and goethite $(\alpha-\mathrm{FeOOH})$ also have similar binding energies (Ding et al., 2000; Missana et al., 2003; Zhang and Jia, 2014). After phosphate adsorption, slight shifts of the $\mathrm{Fe} 2 \mathrm{p}_{3 / 2}$ and $\mathrm{Fe} 2 \mathrm{p}_{1 / 2}$ peaks towards a higher binding energy $(0.1-0.4 \mathrm{eV})$ were observed. The P 2p spectrum of phosphate-treated modified SMER (modification $\mathrm{pH}$ 5) displayed a peak at $133.6 \mathrm{eV}$ (data not shown), which was assumed to be $\mathrm{Fe}-\mathrm{O}-\mathrm{P}$ bonding (Mallet et al., 2013). Therefore, XPS gave evidence of the formation of an ironphosphorus complex.

C 1s spectra (Fig 4) were fitted with four peaks for all SMER samples at $284.8 \mathrm{eV}$, $286.5 \pm 0.1 \mathrm{eV}, 288.1 \pm 0.2 \mathrm{eV}$ and $289.2 \pm 0.4 \mathrm{eV}$, corresponding to $\mathrm{C} 1$ : carbon atoms bond only with carbon and/or hydrogen $(\mathrm{C}-\mathrm{C} / \mathrm{C}-\mathrm{H}) ; \mathrm{C} 2$ : carbon atoms bond with a single oxygen atom $\mathrm{C}-\mathrm{O}$ ); $\mathrm{C} 3$ : carbon atoms bond with two non-carbonyl oxygen atoms or a single carbonyl oxygen atom $(\mathrm{O}-\mathrm{C}-\mathrm{O} / \mathrm{C}=\mathrm{O}) ; \mathrm{C} 4$ carbon atoms bond with a carbonyl and a non-carbonyl group (O-C=O) (Nguila Inari et al., 2006; Pereira et al., 2014; Popescu et al., 2009). After iron modification, the binding energy of C3 had slightly increased and the intensity of $\mathrm{C} 2$ increased when modified in acid ( $\mathrm{pH}$ 5) and neutral ( $\mathrm{pH} 7)$ conditions, which suggested that the structure of SMER had changed due to iron modification. The bond area of $\mathrm{C} 4(\mathrm{O}-\mathrm{C}=\mathrm{O})$ became larger after iron modification, whereas the area decreased after phosphate sorption, indicating that the modification process may activate 
some functional groups such as carboxylic groups and, once treated with phosphate, these functional groups become part of a more complicated iron-phosphate complex.

Fig. 4. a 2-column fitting image

\subsection{Biosorbent modification and sorption test}

The virgin SMER displayed an inadequate capacity $(0.14 \mathrm{mg} \mathrm{P} / \mathrm{g})$ for phosphate sorption, therefore modification of the material was required. Phosphate removal efficiency was found to increase with increasing iron concentration (Fig. 5). The initial concentration of the $\mathrm{Fe}^{3+}$ in the system influences the mass transfer of $\mathrm{Fe}^{3+}$ ions between the solid and aqueous phase (Aryal et al., 2010). Additionally, when more $\mathrm{Fe}^{3+}$ ions were introduced to the system, more iron could be attached to the biosorbent.

Fig. 5. a 1.5-column fitting image

The lowest studied modification $\mathrm{pH}$ (5) was found to be the optimal $\mathrm{pH}$ for the iron modification process. For each modified SMER treated with the same initial iron concentration, higher phosphate removal efficiency was observed at the lowest modification $\mathrm{pH}$. The statistical analyses confirmed that the initial iron concentration and modification $\mathrm{pH}$ and also their interaction were significant in the modification stage ( $\mathrm{p}$ value < 0.05) (Table S1).

The modification $\mathrm{pH}$ is considered to be one of the most critical variables affecting the binding of species. The solution $\mathrm{pH}$ has an effect on the speciation of metal ions in solution and on the ionization of the surface functional groups of biomass. At acidic $\mathrm{pH}$ 
values, $\mathrm{Fe}^{3+}$ and positive hydroxide species of iron dominate, whereas insoluble iron hydroxide is formed in the near-neutral region. At higher $\mathrm{pH}$ values, negative hydroxide species of iron start to dominate. These results were supported by XPS; more iron was introduced onto the SMER in acidic or neutral solutions.

The optimal pH is strongly dependent on the properties of the biomass. For Staphylococus xylosus biomass, the optimal $\mathrm{pH}$ for $\mathrm{Fe}(\mathrm{III})$ uptake was 3 when the effect of $\mathrm{pH}$ was investigated in the $\mathrm{pH}$ range of 1-7 (Aryal et al., 2010). Pagnanelli et al. (2000) investigated the effect of $\mathrm{pH}(3,4$ and 5) on the sorption of iron(III) by Arthrobacter sp. Their results showed that there was a strong increase in the uptake capacity for iron when the $\mathrm{pH}$ was 5, which might have been due to the presence of other mechanisms besides binding by functional groups, such as surface precipitation (taking place locally) and coprecipitation. In the present study, as higher modification $\mathrm{pH}$ values were studied, surface precipitation played an important role in the binding of Fe(III) on SMER.

\subsection{Sorption capacity}

The capacity curve for phosphate sorption by iron-modified SMER at different initial phosphate concentrations is presented in Fig. 6. Two batches of iron-modified SMER were compared. The achieved phosphate sorption capacity of batch 1 and batch 2 with a $24 \mathrm{~h}$ contact time was approx. $9 \mathrm{mg} \mathrm{P} / \mathrm{g}$ and $13 \mathrm{mg} \mathrm{P} / \mathrm{g}$, respectively. The RedlichPeterson model was found to provide the best fit to the experimental data (the lowest chisquared $\left(\chi^{2}\right)$ value and the highest coefficient of determination $\left(\mathrm{R}^{2}\right)$ ) (Table S2, Fig. S2). Batch 2 showed better sorption capacity. The difference may arise from experimental uncertainty, for example the kinetics of $\mathrm{pH}$ adjustment in the modification. Nevertheless, iron-modified SMER showed great potential for phosphate removal. The capacity 
obtained is at the same level as that obtained for other Fe(III)-loaded biomaterials, as shown in Table 1. Further optimization of the procedure (pH and iron concentration) could increase the capacity still further. In addition, pretreatment of biomass has been suggested in order to increase the binding sites for iron. For example, carboxymethyl cellulose treatment of wood fibres and particles enhanced phosphate removal from 0.65-2.78 $\mathrm{mg} \mathrm{P} / \mathrm{g}$ to $2.32-5.67 \mathrm{mg} \mathrm{P} / \mathrm{g}$ (Eberhardt and Min, 2008).

Fig. 6. a single-column fitting image

\subsection{Effect of $\mathrm{pH}$ of aqueous media}

The $\mathrm{pH}$ of the aqueous solution is a critical variable that influences the uptake of anions and cations at solid-liquid interfaces. The sorption of phosphate is highly dependent on the solution $\mathrm{pH}$. Thermodynamic calculations indicate that phosphate exists in aqueous solution in the forms of $\mathrm{H}_{3} \mathrm{PO}_{4}, \mathrm{H}_{2} \mathrm{PO}_{4}{ }^{-}, \mathrm{HPO}_{4}{ }^{2-}$ and $\mathrm{PO}_{4}{ }^{3-}$ in different ratios, depending on the solution $\mathrm{pH}$ (Krishnan \& Haridas, 2008):

$$
\begin{array}{ll}
\mathrm{H}_{3} \mathrm{PO}_{4} \leftrightarrow \mathrm{H}_{2} \mathrm{PO}_{4}^{-}+\mathrm{H}^{+} & \mathrm{p}^{\mathrm{K}_{1}=2.23} \\
\mathrm{H}_{2} \mathrm{PO}_{4}^{-} \leftrightarrow \mathrm{HPO}_{4}^{2-}+\mathrm{H}^{+} & \mathrm{p}^{\mathrm{K}_{2}=7.21} \\
\mathrm{HPO}_{4}^{2-} \leftrightarrow \mathrm{PO}_{4}^{3-}+\mathrm{H}^{+} & \mathrm{p}^{\mathrm{K}_{3}=12.32}
\end{array}
$$

In the $\mathrm{pH}$ range of $3-7, \mathrm{H}_{2} \mathrm{PO}_{4}^{-}$is the major species, whereas when the $\mathrm{pH}$ value is between 7.2 and $12.3, \mathrm{HPO}_{4}{ }^{2-}$ is the predominant species.

The effect of $\mathrm{pH}$ on phosphate uptake is shown in Fig. 7. A strongly acidic environment was avoided in the experiment since a strong acid solution might have led to the destabilization of the biosorbent and iron leaching would have become more likely. Hence, the effect of the solution $\mathrm{pH}$ value on phosphate sorption was studied in the range 
of 3-9. As shown in Fig. 7, phosphate removal efficiency decreased as the pH value increased. The maximum phosphate removal efficiency reached $82 \%$ at $\mathrm{pH} 3$ (initial concentration $15 \mathrm{mg}$ P/L). In addition, more than $50 \%$ of phosphate was removed when the solution $\mathrm{pH}$ was in the range of 3-5. In contrast, inadequate phosphate uptake was observed in alkaline conditions. Considering that it is not always practical to apply low $\mathrm{pH}$ in real activities, a $\mathrm{pH}$ value of 4 was selected for subsequent experiments.

Fig. 7. a single-column fitting image

Several studies have revealed a similar effect of $\mathrm{pH}$ on phosphate sorption behaviour, i.e. that phosphate sorption was maximized at a pH value in the range of 3-6 (Cui et al., 2016; Liao et al., 2006). In addition, our results were consistent with a previous study conducted by Krishnan and Haridas (2008). They prepared natural and iron-modified coir pith for phosphate sorption, and it was reported that the $\mathrm{pH}$ PZC (by potentiometric titration) of iron-modified coir pith was observed at $\mathrm{pH}$ 5.8. This means that the iron-modified biomass had a net positive surface charge when the $\mathrm{pH}$ was lower than 5.8. Thus, the attachment of negatively charged phosphate species $\left(\mathrm{H}_{2} \mathrm{PO}_{4}^{-}\right)$was favoured when the $\mathrm{pH}$ was lower than 5.8. However, the value of $\mathrm{pH}_{\mathrm{PZC}}$ can vary for different iron materials. For two-line ferrihydrite, which was found to be the iron form on the SMER according to $\mathrm{XRD}$, the $\mathrm{pH}_{\mathrm{IEP}}$ (isoelectric point, by zeta potential measurements) is around $\mathrm{pH} 7$ (Chernyshova et al., 2011).

The low phosphate sorption capacity at high $\mathrm{pH}$ values was due to the more negative surface above the $\mathrm{pH}_{\mathrm{PZC}}$ and thus increased electrostatic repulsion between the surface and negatively charged phosphate ions. In addition, the concentration of $\mathrm{OH}^{-}$became higher and hydroxides competed with phosphate species for binding sites at high $\mathrm{pH}$ 
values. The suggested mechanism for phosphate sorption on similar iron materials involves the ligand exchange for hydroxyl ions and the formation of an inner-sphere complex (Krishnan and Haridas, 2008).

\subsection{Effect of contact time}

Fig. 8 presents phosphate sorption on iron-modified SMER as a function of time (initial concentration of $15 \mathrm{mg} \mathrm{P} / \mathrm{L}$ and $\mathrm{pH}$ 4). The phosphate removal efficiency slowly increased within the first hour, reaching $26 \%$ after $6 \mathrm{~h}$. Subsequently, the removal efficiency continued to increase up to $70 \%$ after $48 \mathrm{~h}$ contact time. Three kinetic models (pseudo-first-order, pseudo-second-order and Elovich) were used to analyse the kinetic data (supplementary material). Considering both the correlation co-efficient $\left(\mathrm{R}^{2}\right)$ and the chi-squared $\left(\chi^{2}\right)$ value, the Elovich model was found to provide the best fit to the kinetic data (Table S3, Fig. S3). The Elovich model is known to describe the kinetics of chemisorption well (Tran et al. 2017).

Reaching equilibrium is a slow process for amorphous iron materials due to the significant role of the pore diffusion mechanism (Swedlund et al., 2014; Sigdel et al., 2016). Sigdel et al. (2016) reported that alginate beads impregnated with hydrous iron oxide reached equilibrium for arsenic adsorption after around seven days. The hydrous iron oxide was confirmed to be two-line ferrihydrite and the As(V) adsorption was mainly governed by intra-particle diffusion.

Fig. 8. a single-column fitting image

\section{Conclusions}


The iron loading of Sphagnum moss extract residue (SMER), a waste material, resulted in an effective sorbent for phosphate removal. A modification $\mathrm{pH}$ of 5 and the highest initial $\mathrm{Fe}(\mathrm{III})$ concentration $\left(0.072 \mathrm{~mol} / \mathrm{L} \mathrm{Fe}^{3+}\right)$ were observed to be the optimal modification conditions. According to XPS, more iron could be attached to the surface of SMER in an acidic solution. FTIR analysis proved that carboxylic acid functional groups $(-\mathrm{COOH})$ were able to capture metal ions during the modification process, whereas XRD analysis confirmed that two-line ferrihydrite was precipitated on the SMER. Phosphate sorption was greatly affected by the $\mathrm{pH}$ (maximum removal at $\mathrm{pH} 3$ ) and contact time. These results corroborate the fact that iron-modified SMER can be used effectively as a low-cost and eco-friendly biosorbent for phosphate removal from wastewaters such as agriculture run-offs. Used sorbent could be safely disposed of in soil as a phosphate fertiliser provided that no toxic components from the treated wastewater are attached. Moreover, the biosorbent material itself would improve the physical properties of the soil.

\section{Acknowledgments}

The Natural Resources Institute of Finland provided the material, i.e. peat moss residue, for this research. The research was funded by Maa- ja vesitekniikan tuki ry. and the European Regional Development Fund (as part of the SuoBio project, "Sustainable refining of peatland biomasses into valuable products").

\section{References}

1. Adegoke. H.I., Adekola. F.A., Fatoki, O.S., Ximba. B.J., 2013. Sorptive interaction of oxyanions with iron oxides: a review. Pol. J. Environ. Stud. 22: 7-24.

2. Ali, I., Al-Othman, Z. A., Alwarthan, A., 2016a. Molecular uptake of congo red dye from water on iron composite nano particles. J Mol Liq 224, 171-176. 
3. Ali, I., Al-Othman, Z. A., Alwarthan, A., 2016b. Synthesis of composite iron nano adsorbent and removal of ibuprofen drug residue from water. J. Mol. Liq. 219, 858864.

4. Ali, I., Al-Othman, Z. A., Alwarthan, A., Asim, M., Khan, T.A., 2014. Removal of arsenic species from water by batch and column operations on bagasse fly ash. Environ. Sci. Pollut. Res. 21, 3218-3229.

5. Ali I., Alothman, Z. A., Sanagi, M.M., 2015. Green synthesis of iron nanoimpregnated adsorbent for fast removal of fluoride from water. J. Mol. Liq. 211, 457465.

6. Ali, I., Asim, M., Khan, T.A., 2012. Low cost adsorbents for the removal of organic pollutants from wastewater. J. Environ. Manage. 113, 170-183.

7. Aryal, M., Ziagova, M., Liakopoulou-Kyriakides, M., 2010. Study on arsenic biosorption using Fe(III)-treated biomass of Staphylococcus xylosus. Chem. Eng. J. $162,178-185$.

8. Baas, M., Pancost, R., Geel, B.V., Damsté, J.S.S., 2000. A comparative study of lipids in Sphagnum species. Org. Geochem. 31, 535-541.

9. Babel, S., Kurniawan, T.A., 2003. Low-cost adsorbents for heavy metals uptake from contaminated water: a review. J. Hazard. Mater. 97, 219-243.

10. Bhatnagar, A., Minocha, A.K., 2006. Conventional and non-conventional adsorbents for removal of pollutants from water-A review. Indian J. Chem. Technol. 13, 203217.

11. Biswas, B.K., Inoue, K., Ghimire, K.N., Ohta, S., Harada, H., Ohto, K., Kawakita, H., 2007. The adsorption of phosphate from an aquatic environment using metal-loaded orange waste. J. Colloid Interface Sci. 312, 214-223.

12. Bulgariu, L., Bulgariu, D., Macoveanu, M., 2011. Adsorptive performances of alkaline treated peat for heavy metal removal. Sep. Sci. Technol. 46, 1023-1033.

13. Charman, D., 2002. Peatlands and Environmental Change. John Wiley \& Sons, Chichester.

14. Chernyshova, I.V, Ponnurangam, S., Somasundaran, P., 2011. Effect of nanosize on catalytic properties of ferric (hydr)oxides in water: Mechanistic insights. J. Catalysis. $282,25-34$.

15. Cornell, R.M., Schwertmann. U., 2003. The Iron Oxides: Structure, Properties, Reactions, Occurrences and Uses. Wiley-VCH, Weinheim.

16. Crini, G., 2006. Non-conventional low-cost adsorbents for dye removal: a review. Bioresour. Technol. 97, 1061-1085.

17. Cui, G., Liu, M., Chen, Y., Zhang, W., Zhao, J., 2016. Synthesis of a ferric hydroxidecoated cellulose nanofiber hybrid for effective removal of phosphate from wastewater. Carbohydr. Polym. 154, 40-47.

18. Das, S., Hendry, M.J., Essilfie-Dughan, J., 2010. Transformation of two-line ferrihydrite to goethite and hematite as a function of $\mathrm{pH}$ and temperature. Environ. Sci. Technol. 45, 268-275. 
19. Dehghani, M.H., Sanaei, D., Ali, I., Bhatnagar, A., 2016. Removal of chromium (VI) from aqueous solution using treated waste newspaper as a low-cost adsorbent: kinetic modeling and isotherm studies, J. Mol. Liq. 215, 671-679.

20. Ding, M., de Jong, B. H. W. S., Roosendaal, S. J., Vredenberg, A., 2000. XPS studies on the electronic structure of bonding between solid and solutes: adsorption of arsenate, chromate, phosphate, $\mathrm{Pb}^{2+}$, and $\mathrm{Zn}^{2+}$ ions on amorphous black ferric oxyhydroxide. Geochim. Cosmochim. Acta. 64, 1209-1219.

21. Eberhardt, T.L., Min, S.-H., 2008. Biosorbents prepared from wood particles treated with anionic polymer and iron salt: effect of particle size on phosphate adsorption. Bioresour. Technol. 99, 626-630.

22. Frau, F., Addari, D., Atzei, D., Biddau, R., Cidu, R., Rossi, A., 2010. Influence of major anions on As (V) adsorption by synthetic 2-line ferrihydrite. Kinetic investigation and XPS study of the competitive effect of bicarbonate. Water, Air, Soil Pollut. 205, 25-41.

23. Gamenara, D., Pandolfi, E., Saldaña, J., Domínguez, L., Martínez, M.M., Seoane, G., 2001. Nematocidal activity of natural polyphenols from bryophytes and their derivatives. Arzneim.-Forsh. 51, 506-510.

24. Gardea-Torresdey, JL., Tang, L., Salvador, J.M., 1996. Copper adsorption by esterified and unesterified fractions of Sphagnum peat moss and its different humic substances. J. Hazard. Mater. 48, 191-206.

25. Gupta, V.K., Ali, I., 2012. Environmental Water: Advances in Treatment, Remediation and Recycling. Elsevier, Amsterdam.

26. Khan, T.A., Sharma, S., Ali, I., 2011. Adsorption of rhodamine B dye from aqueous solution onto acid activated mango (Magniferaindica) leaf powder: equilibrium, kinetic and thermodynamic studies. J. Toxicol. Environ. Health Sci. 3, 286-297.

27. Kilpeläinen, P.O., Hautala, S.S., Byman, O.O., Tanner, L.J., Korpinen, R.I., Lillandt, M.K-J., Pranovich, A.V., Kitunen, V.H., Willför, S.M., Ilvesniemi, H.S., 2014. Pressurized hot water flow-through extraction system scale up from the laboratory to the pilot scale. Green Chem. 16, 3186-3194.

28. Krishnan, K.A., Haridas, A., 2008. Removal of phosphate from aqueous solutions and sewage using natural and surface modified coir pith. J. Hazard. Mater. 152, 527-535.

29. Lewis, D.G., Cardile, C.M., 1989. Hydrolysis of Fe ${ }^{\mathrm{III}}$ solution to hydrous iron oxides. Soil Res. 27, 103-115.

30. Li, C., Chen, H.Z., Li, Z.H., 2004. Adsorptive removal of $\mathrm{Cr}(\mathrm{VI})$ by Fe-modified steam exploded wheat straw. Process Biochem. 39, 541-545

31. Liao, X.P., Ding, Y., Wang, B., Shi, B., 2006. Adsorption behavior of phosphate on metal-ions-loaded collagen fiber. Ind. Eng. Chem. Res. 45, 3896-3901.

32. Mallet, M., Barthélémy, K., Ruby, C., Renard, A., Naille, S., 2013. Investigation of phosphate adsorption onto ferrihydrite by X-ray photoelectron spectroscopy. J. Colloid Interface Sci. 407, 95-101.

33. Mathew, T., Suzuki, K., Nagai, Y., Nonaka, T., Ikuta, Y., Takahashi, N., Suzuki, N., Shinjoh, H., 2011. Mesoporous 2- Line Ferrihydrite by a Solution- Phase Cooperative 
Assembly Process for Removal of Organic Contaminants in Air. Chem. Eur. J. 17, 1092-1095.

34. Missana, T., García-Gutiérrez, M., Maffiotte, C., 2003. Experimental and modeling study of the uranium (VI) sorption on goethite. J. Colloid Interface Sci. 260, 291-301.

35. Nguila Inari, G., Petrissans, M., Lambert, J., Ehrhardt, J.J., Gérardin, P., 2006. XPS characterization of wood chemical composition after heat- treatment. Surf. Interface Anal. 38, 1336-1342.

36. Nguyen, T.A.H., Ngo, H.H., Guo, W.S., Zhang, J., Liang, S., Tung, K.L., 2013. Feasibility of iron loaded 'okara' for biosorption of phosphorous in aqueous solutions. Bioresour. Technol. 150, 42-49.

37. Pagnanelli, F., Petrangeli Papini, M., Toro, L., Trifoni, M., Veglio, F., 2000. Biosorption of metal ions on Arthrobacter sp.: biomass characterization and biosorption modeling. Environ. Sci. Technol. 34, 2773-2778.

38. Pereira, P.H.F., Voorwald, H.J.C., Cioffi, M.O.H., Da Silva, M.L.C.P., Rego, A.M.B., Ferraria, A.M., De Pinho, M.N., 2014. Sugarcane bagasse cellulose fibres and their hydrous niobium phosphate composites: synthesis and characterization by XPS, XRD and SEM. Cellulose. 21, 641-652.

39. Popescu, C.M., Tibirna, C.M., Vasile, C., 2009. XPS characterization of naturally aged wood. Appl. Surf. Sci. 256, 1355-1360.

40. Schwertmann, U., Friedl, J., Stanjek, H., 1999. From Fe (III) ions to ferrihydrite and then to hematite. J. Colloid Interface Sci. 209, 215-223.

41. Sigdel, A., Park, J., Kwak, H., Park, P.K., 2016. Arsenic removal from aqueous solutions by adsorption onto hydrous iron oxide-impregnated alginate beads. J. Ind. Eng. Chem. 35, 277-286.

42. Swedlund, P.J., Holtkamp, H., Song, Y., Daughney, C.J., 2014. Arsenate-ferrihydrite systems from minutes to months: a macroscopic and IR spectroscopic study of an elusive equilibrium. Environ. Sci. Technol. 48, 2759-2765.

43. Tarnawski, M., Depta, K., Grejciun, D., Szelepin, B., 2006. HPLC determination of phenolic acids and antioxidant activity in concentrated peat extract-a natural immunomodulator. J. Pharm. Biomed. Anal. 41, 182-188.

44. Tran, H.N., You, S.-J., Hosseini-Bandegharaei, A., Chao, H.-P. (2017) Mistakes and inconsistencies regarding adsorption of contaminants from aqueous solutions: A critical review. Water Res. 120: 88-116.

45. Yamada, P., Isoda, H., Han, J.K., Talorete, T.P.N., Yamaguchi, T., Abe, Y., 2007. Inhibitory effect of fulvic acid extracted from Canadian sphagnum peat on chemical mediator release by RBL-2H3 and KU812 cells. Biosci. Biotechnol. Biochem. 71, 1294-1305.

46. Xu, X., Gao, B., Jin, B., Yue, Q., 2016. Removal of anionic pollutants from liquids by biomass materials: A review. J Mol. Liq. 215: 565-595.

47. Zhang, Y.X., Jia, Y., 2014. A facile solution approach for the synthesis of akaganéite $(\beta-\mathrm{FeOOH})$ nanorods and their ion-exchange mechanism toward $\mathrm{As}(\mathrm{V})$ ions. Appl. Surf. Sci. 290, 102-106. 


\section{FIGURE CAPTIONS}

Fig. 1. X-ray diffraction profiles of virgin, iron-modified (Fe-SMER) and phosphatetreated iron-modified SMER (P-Fe-SMER) samples.

Fig. 2. FTIR spectra of virgin and iron-modified SMER (pH 5 with $0.072 \mathrm{~mol} / \mathrm{L} \mathrm{Fe}^{3+}$ concentration).

Fig. 3. O 1s spectra of SMER: (a) virgin SMER; (b) iron-modified SMER at pH 5; (c) iron-modified SMER at $\mathrm{pH} 7$; (d) iron-modified SMER at $\mathrm{pH}$ 9; (e) phosphate-treated iron-modified SMER at $\mathrm{pH} 5$.

Fig. 4. C 1s spectra of (a) virgin SMER; (b) iron-modified SMER at pH 5; (c) ironmodified SMER at pH 7; (d) iron-modified SMER at pH 9; (e) phosphate-treated ironmodified SMER at $\mathrm{pH} 5$.

Fig. 5. Effect of modification conditions on phosphate sorption (Biosorbent dose $2 \mathrm{~g} / \mathrm{L}$; Contact time $24 \mathrm{~h}$; Sorption solution pH 6; Initial phosphate concentration $15 \mathrm{mg} \mathrm{P} / \mathrm{L}$; Temperature $20 \pm 3^{\circ} \mathrm{C}$; Error bars represent the deviation of four repeats (two products made in same conditions and two shaking tests for each product).

Fig. 6. Phosphate-P sorption capacity by iron-modified SMER at $\mathrm{pH} 5$ with $0.072 \mathrm{~mol} / \mathrm{L}$ $\mathrm{Fe}^{3+}$ concentration (Biosorbent dose $2 \mathrm{~g} / \mathrm{L}$; Contact time $24 \mathrm{~h}$; Sorption solution $\mathrm{pH}$ 4; Temperature $20 \pm 3^{\circ} \mathrm{C}$; Error bars represent the deviation of three repeats).

Fig. 7. Effect of $\mathrm{pH}$ on phosphate removal by iron-modified SMER at $\mathrm{pH} 5$ with 0.072 mol/ $\mathrm{L} \mathrm{Fe}^{3+}$ concentration (Biosorbent dose $2 \mathrm{~g} / \mathrm{L}$; Contact time $24 \mathrm{~h}$; Initial phosphate concentration $15 \mathrm{mg} \mathrm{P} / \mathrm{L}$; Temperature $20 \pm 3{ }^{\circ} \mathrm{C}$; Error bars represent the deviation of two repeats).

Fig. 8. Effect of contact time on phosphate removal by iron-modified SMER at $\mathrm{pH} 5$ with $0.072 \mathrm{~mol} / \mathrm{L} \mathrm{Fe}^{3+}$ concentration (Biosorbent dose $2 \mathrm{~g} / \mathrm{L}$; Sorption solution $\mathrm{pH} 4$; Initial phosphate concentration $15 \mathrm{mg} \mathrm{P} / \mathrm{L}$; Temperature $20 \pm 3{ }^{\circ} \mathrm{C}$; Error bars represent the deviation of two repeats). 